\title{
Explaining the Variations in the Pedestrian Flow Values of Shopping Centres*
}

\author{
Dr. Bonnie Y.M. LAM \\ Hong Kong College of Technology \\ Centre of International Education \\ Prof. K.W. CHAU \\ The University of Hong Kong \\ Department of Real Estate and Construction
}

\begin{abstract}
Purpose - The purpose of this paper is to identify and analyze the crucial variables of pedestrian flow value of the shopping centres in Hong Kong.

Design/ methodology/ approach - This study identifies the key determinants of pedestrian flow value (PFV) which is measured by net rental income per floor area per pedestrian flow. Based on the rental and pedestrian flow survey data of 146 shopping centres along the subway (Mass Transit Railway) stations in Hong Kong, we have estimated the marginal effects of these determinants on the PFV.

Findings - The research explains different variations' impacts of pedestrian flow on the rental value of the shopping centres in Hong Kong. It is found that shopping centres owned by the same owners tend to achieve a lower PFV, which suggests that owners of multiple shopping malls may adopt a uniform pedestrian flow management strategy that may not be ideal for each individual mall.

Research limitations/ implications - This study is on the shopping centres that are located along the railway stations. Researchers are encouraged to test the shopping centres that are with less effect from the railway stations.

Practical implications - It is useful for the shopping centre owners and operators to determine the optimal strategy for managing pedestrian flow in their shopping centres.

Originality/value - The relationship between pedestrian flow and the shopping centre value is coined in the research as Pedestrian Flow Value (PFV) which is to calculate the pedestrian flow effectiveness measured by net rental income per floor area per pedestrian flow.

Keywords - Management strategy, pedestrian flow, rent, shopping centre, Pedestrian Flow Value (PFV)

Paper type - Research paper
\end{abstract}

\section{*Accepted for publication in Facilities} Suggested Citation:

Lam, B.Y.M. and Chau, K. W. (2012) "Explaining the Variations in the Pedestrian Flow Values of Shopping Centres" (2012), Facilities, 30, 3/4 , 164-175. 


\section{Introduction}

Pedestrian flow is an important performance indicator of shopping centres because getting people into the "store" is with the hope of getting them to buy something from the mall (Moss, 2007). In the property market, it is quite common that the rental of the shops located at the area with higher pedestrian flow commands a higher charge. In fact, pedestrian flow is not only an indicator to show the popularity of the shopping centre but also an important element to reflect the value of the whole portfolio. If the shopping centre is not able to maintain enough number of pedestrians, it may indicate that the shopping centre is unable to attract sufficient business patronages. However, pedestrian flow cannot be increased without costs and that such costs often increase at an increasing rate as pedestrian flow increases. The financial benefit (increase in rental value) of increasing pedestrian flow is not the same for different shopping centres. Therefore, it may not always be beneficial to spend resources on increasing pedestrian flow.

In fact, there are different kinds of researches dedicated to the relationship between physical or location characteristics and pedestrian flow amount/ pedestrian speed such as the research on pedestrian moving pattern in major shopping districts that was carried out by the Planning Department of Hong Kong Government (Planning Dept., 2007) and the experimental researches of pedestrian walking behaviour by Delft University of Technology (Cheung \& Lam, 1998; Daamen \& Hoogendoorn, 2003). There are also studies about management factors on pedestrian flow such as the effect of management style (Davies, 1977b; Lea \& Menger 1991; Anon, 1969) and renovation frequencies (Lea $\&$ Menger, 1991). Previous studies mainly focused on how the physical and location characteristics of shopping centres affect pedestrian flow. There has been no empirical study of relationship between how pedestrian flow can affect the shopping centres' rental.

\section{Objectives of the Research}

In many cities of the world today, the volume of pedestrian flow has been one of the considerations during rental negotiation. The underlying assumption is that an increase in pedestrian flow can lead to higher shopping centre rent. While this assumption is in general true, the effect of increase in pedestrian flow on rental level of shopping centres varies across different shopping centres. That is, the value of the pedestrian flow to owner of shopping centres or Pedestrian Flow Value (PFV), in term of its positive impact to shopping centre rent, is in general positive but its magnitude can vary significantly across different shopping centres. The aim of this research is not to suggest that the shopping centres should maximize the PFV of their shopping centres but to explain the variations in the PFV across different shopping centres. The objectives of this research are shown as below:

1. To identity the effects of the observable factors and examine how these factors affect the PFV of the shopping centres.

2. To develop hypotheses that explains the variation in PFV.

3. To test the hypotheses developed in (2) with empirical data

4. To identify the practical implications for shopping centre management. 


\section{Pedestrian Flow Value (PFV)}

To determine an optimal strategy for managing pedestrian flow in a shopping center, we have to understand the factors that affect the value of pedestrian flow to the owners of the shopping centres. This paper introduces a new concept in the calculation of PFV of the shopping centre. It is to work out the per flow value by the net rental income per floor area per pedestrian flow.

\section{Determinants of PFV}

The determinants of PFV being adopted in this study can be categorized into the following five areas:

1. Physical characteristics which include internal floor area (IFA), number of storeys of the shopping centre, number of entrances at the major walking level(s), availability of car parking spaces, and building age.

2. Location characteristics that include distance from the major shopping districts (MSD), types of adjacent properties i.e. whether the adjacent property is a residential or non-residential development? What is the median household income in the catchment area?

3. Owner and tenant characteristics that include majority ownership, number of shopping centres owned by the same owner in the city, and themed shopping centre effect.

4. Number of pedestrians of the shopping centre.

5. Rateable value per square meter of the shopping centre.

To work out the per flow value by the net rental income per floor area per pedestrian flow, the following hypotheses are established:

\section{Hypothesis on Physical Characteristics}

1-1 Internal floor area (IFA) has a negative impact on the PFV ceteris paribus

1-2 Number of storeys has a negative impact on the PFV ceteris paribus

1-3 Number of entrances has a negative impact on the PFV ceteris paribus

1-4 Car park has a negative impact on the PFV ceteris paribus

1-5 Building age has no impact on the PFV ceteris paribus

Regarding the physical features, we trust internal floor area (IFA) (Eppli \& Shilling, 1996; Daamen \& Hoogendoorn, 2003; Gambill, 2000; Reimers \& Clulow, 2004), number of storeys (Ordway, et al., 1988), number of entrances (Ordway, et al., 1988; Reimers \& Clulow, 2004), and car park are with negative impacts on the PFV ceteris paribus. However, building age should have no impact on the PFV of the shopping centre as the negative effect caused by the old age of the building can usually be off set by frequent physical makeup (Eppli \& Shilling, 1996; Daamen \& Hoogendoorn, 2003; Gambill, 2000; Reimers \& Clulow, 2004). 


\section{Hypothesis on Location Characteristics}

2-1 Distance from the major shopping district (MSD) has a negative impact on the PFV ceteris paribus

2-2 PFV of Residential shopping centres is lower than that of Commercial shopping centres ceteris paribus

2-3 Proximity to other competing shopping centre(s) has a negative impact on the PFV ceteris paribus

2-4 The PFV of shopping centre is higher in the areas of higher household income, ceteris paribus

About the location effects, we trust distance from the major shopping district (MSD) (The Economist, 01/03/2007; Cheng, et al., 2005), adjacent to the residential developments, and neighbouring to competitor shopping centre(s) are all with negative impacts on the PFV ceteris paribus (Ownbey, et al., 1994; Sirpal, 1994; Tse, 2002). However, if the shopping centre is located at a higher median household income area, its effect on the PFV should then be positive due to the higher purchasing power in the area.

\section{Hypothesis on Owner and Tenant Characteristics}

3-1 Majority ownership has a positive impact on PFV ceteris paribus

3-2 The PFV is lower for shopping centres owned by owner of multiple shopping centres, ceteris paribus

\section{3-3 Themed shopping centre has higher PFV ceteris paribus}

Regarding the owner and tenant characteristics, we believe that majority ownership has a positive impact on the PFV ceteris paribus as a better managed majority ownership shopping centre is able to attract more business patronages and maintain a higher rental level (Tse, 2002; Gambill, 2000; Kenney, 2000; Sicard, 2001; Simkin, 1989; Singer, 1995; Sloot, et al., 2005; Tse, 2002). However, shopping centres owned by the owner of multiple shopping centres should have a negative impact on the PFV ceteris paribus. These owners are often large companies with the management philosophy focuses on the brand building of the shopping centres. Such uniform management methods may not be suitable for all the shopping centres operated under the same umbrella.

About the tenant characteristics, we believe themed shopping centres should have a positive impact on the PFV ceteris paribus because most of the pedestrians in the themed shopping centres are purposed shoppers (Fung, 2000; Skyat-Kengingwiluya, 2002).

\section{Hypothesis on Pedestrian Flow Density}

Entrance floor flow density (EFFD) has a negative impact on the PFV ceteris paribus

The entrance floor flow density (EFFD) of the shopping centre is an important factor to affect the shopping atmosphere of the shopping centre. We trust the PFV of the shopping centres will be negative if the entrance density has become too crowded ceteris paribus (Chun, Eppli, \& Shilling, 2001). 


\section{Hypothesis on Rateable Value Characteristics}

\section{Rateable value per floor area has a positive effect on to the PFV ceteris paribus}

We also believe rateable value is positive to the PFV of the shopping centre ceteris paribus. As a matter of logic inference, the tenants of a high rateable value (high rental) shopping centre often need to provide more luxury merchandises in order to cover their high rental expenses. Similarly, the shoppers that go for high value items also like to go to the high-end shopping centres for their desirable items.

\section{Empirical Model of PFV}

The empirical model being adopted in this research is:

$P F V=f(X, L, O T, F, R)$

where

$\mathbf{X}$ is a vector of physical characteristics variables

$\mathbf{L} \quad$ is a vector of location characteristics variables

OT is a vector of owner and tenant characteristics variables

F is the pedestrian flow variable

$\mathbf{R}$ is the rateable value variable

The model implies that the PFV (i.e. rental income generated by each pedestrian) of a shopping centre is a function (f) of the physical features $(\mathbf{X})$, location factors $(\mathbf{L})$, owner and tenant characteristics (OT), pedestrian flow (F), and Rateable Value (R). To operationalize the empirical model, we have adopted the following semi-log model and estimate the coefficients using OLS technique:

$\ln (\mathrm{PFV})=\mathrm{a}_{0}+\mathrm{a}_{1} \mathrm{IFA}+\mathrm{a}_{2} \mathrm{ST}+\mathrm{a}_{3} \mathrm{NOE}+\mathrm{a}_{4} \mathrm{CP}+\mathrm{a}_{5} \mathrm{AGE}+\mathrm{a}_{6} \mathrm{MSD}+\mathrm{a}_{7} \mathrm{RES}+\mathrm{a}_{8} \mathrm{COMP}+$ $\mathrm{a}_{9}$ RES $*$ INCOME $+\mathrm{a}_{10} \mathrm{OWN}+\mathrm{a}_{11} \mathrm{NOMO}+\mathrm{a}_{12}$ THEME $+\mathrm{a}_{13}$ EFFD $+\mathrm{a}_{14}$ RVM $+\epsilon$

IFA is the total internal floor area of the shopping centre according to the data from Rating \& Valuation Department of Hong Kong Government

ST is a dummy variable that equals to 1 if the number of storey is more than $\mathrm{n}$ which is to be determined empirically and zero otherwise

NOE is the total number of entrances of the shopping centre at street/ footbridge/ railway exit level

$\mathrm{CP}$ is a dummy variable that equals to 1 if the shopping centre is 
provided with car parking spaces and zero otherwise

AGE is the building age (in year)

MSD is the number of MTR stations (or Light Rail station in New Territories) from the nearest major shopping districts (Causeway Bay for Hong Kong Island; Mongkok for Kowloon Peninsula; and Shatin for New Territories)

RES is a dummy variable that equals to 1 if it is a Residential shopping centre and zero otherwise

COMP is a dummy variable that equals to 1 if there is at least one shopping centre within 7 minutes walking distance and zero otherwise

RES*INCOME is the median income of the catchment area within 200 sq.m. from the shopping centre

OWN is a dummy variable equals to 1 if one major owner owns more than $50 \%$ of the shopping centre and zero otherwise

NOMO is the number of shopping centres in Hong Kong owned by the major owner who owns over $50 \%$ share in the shopping centre

THEME is a dummy variable equals to 1 if more than $50 \%$ of the merchandizes belongs to the same theme of products and zero otherwise

EFFD is the main entrance floor flow density that is calculated by the dividing total pedestrian flow by main entrance floor area

RVM is a high-end shopping centre dummy equals to 1 if the rateable value per internal floor area is larger than the medium rateable value per internal floor area as per year 2007/2008 and zero otherwise

$\mathrm{a}_{\mathrm{i}}$ are coefficients to be estimated; and

$C$ is the stochastic term. 


\section{Expected Results}

The expected results of this test are shown in the following table:

\begin{tabular}{|l|c|c|}
\hline \multicolumn{1}{|c|}{ Independent Variable } & Coefficient & Expected Sign \\
\hline Internal floor area & $\mathrm{a}_{1}$ & -ve \\
\hline No. of storeys & $\mathrm{a}_{2}$ & -ve \\
\hline No. of entrances & $\mathrm{a}_{3}$ & -ve \\
\hline Car park & $\mathrm{a}_{4}$ & -ve \\
\hline Building Age & $\mathrm{a}_{5}$ & $?$ \\
\hline $\begin{array}{l}\text { Distance from major shopping districts } \\
\text { (MSD) }\end{array}$ & $\mathrm{a}_{6}$ & -ve \\
\hline Residential shopping centre & $\mathrm{a}_{7}$ & -ve \\
\hline Close to competitor shopping centres & $\mathrm{a}_{8}$ & -ve \\
\hline Median Household Income & $\mathrm{a}_{9}$ & $+\mathrm{ve}$ \\
\hline Majority ownership & $\mathrm{a}_{10}$ & $+\mathrm{ve}$ \\
\hline Owner of multiple shopping centres & $\mathrm{a}_{11}$ & -ve \\
\hline Themed shopping centre & $\mathrm{a}_{12}$ & $+\mathrm{ve}$ \\
\hline Entrance floor flow density (EFFD) & $\mathrm{a}_{13}$ & -ve \\
\hline Rateable Value & $\mathrm{a}_{14}$ & $+\mathrm{ve}$ \\
\hline
\end{tabular}

\section{Data for Empirical Tests}

The study and data collection of this research is based on the rental and pedestrian flow survey data of 146 shopping centres along the subway (Mass Transit Railway) stations in Hong Kong. All these shopping centres are within 5 minutes walking distance from the exits of the MTR stations. The data and sources are collected by the following means:

- Physical characteristics data was collected from the shopping centres' floor plans, building plans, photos, and onsite inspection.

- Location characteristics data was collected from map, location plans, and onsite inspection.

- Ownership and tenant data was collected by onsite observation, owner companies' annual reports and publications.

- Rateable value and internal floor area data was collected from Rating and Valuation Department of Hong Kong Government.

- Median household income of the catchment area was collected from Census and Statistics Department of Hong Kong Government.

- Number of pedestrian flow was collected manually at a fixed time frame by a designated group of helpers. More details are shown in the following paragraph. 


\section{Pedestrian flow Data Collection}

A designated group of helpers were employed and assigned with a manual tally for counting the actual "in flow" number of pedestrian flow at every entrance of the 146 sample shopping centres under the following rules:

- To count all the "in flow" pedestrians at the shopping centre excluding the immediate passing-by people i.e. to rule out those who "flow in" to the shopping centre from the MTR station and immediately "flow out" from the shopping centre through the adjacent exit.

- To count all the entrances at the shopping centre.

- To count the pedestrian amount at each entrance for 15 minutes.

- To count all the pedestrians to include the wheelchair users but to exclude hand holding infants.

- $\quad$ To count at 1430 to 1730 during the weekdays excluding public holidays.

\section{Summary of Data Statistics}

The statistic data of the variables for the 146 sample shopping centres is summarized in the following table:

\begin{tabular}{|c|c|c|c|c|}
\hline & Minimum & Maximum & Mean & $\begin{array}{c}\text { Standard } \\
\text { Deviation } \\
\end{array}$ \\
\hline $\begin{array}{l}\text { Total internal floor area } \\
\text { (IFA) in sq.ft. }\end{array}$ & $4,773 \mathrm{ft}^{2}$ & $909,666 \mathrm{ft}^{2}$ & $124,647 \mathrm{ft}^{2}$ & $157,422.68 \mathrm{ft}^{2}$ \\
\hline Total number of Storey & 1 & 20 & 4.38 & 3.34 \\
\hline $\begin{array}{l}\text { Total number of } \\
\text { entrances at major } \\
\text { walking level(s) }\end{array}$ & 1 & 13 & 3.70 & 2.83 \\
\hline Building Age & 2 years & 55 years & 19.65 years & 10.17 years \\
\hline $\begin{array}{l}\text { Railway stations from } \\
\text { major shopping districts } \\
\text { (MSD) }\end{array}$ & 0 & 19 & 4.671 & 4.61 \\
\hline $\begin{array}{l}\text { Number of shopping } \\
\text { centres owned/ managed } \\
\text { by the same operator in } \\
\text { HK }\end{array}$ & $\begin{array}{c}0 \\
\left({ }^{*} N 1\right)\end{array}$ & $\begin{array}{c}151 \\
\left({ }^{*} N 2\right)\end{array}$ & 23 & 36.59 \\
\hline $\begin{array}{l}\text { Median monthly } \\
\text { household income within } \\
\text { the surrounding } 200 \mathrm{~m}^{2}\end{array}$ & $\mathrm{HK} \$ 8,000$ & $\mathrm{HK} \$ 75,000$ & HK $\$ 16,717$ & $\mathrm{HK} \$ 14,797.87$ \\
\hline $\begin{array}{l}\text { Total Pedestrian Flow } \\
\text { head count within } 15 \\
\text { minutes }\end{array}$ & 10 & 3375 & 559.66 & 564.88 \\
\hline
\end{tabular}

*N1 The owner with zero number of shopping centre ownership refers to the multi-owned shopping centres.

N2 The owner that owns 151 shopping centres in Hong Kong is Link REIT. 


\section{Results and Discussion}

The result of the effects on the PFV in this study is shown in the following table and discussed after in owner and tenant, rateable value, entrance floor flow density, location, and physical characteristics:

Dependent Variable: LOG(RV_M/FLOW)

Included observations: 128 after adjustments

\begin{tabular}{|c|c|c|c|}
\hline Variable & Coefficient & t-Statistic & P-value \\
\hline Constant & 5.499 & 23.930 & 0.000 \\
\hline IFA & $-6.79 \times 10^{-5}$ & -6.016 & 0.000 \\
\hline IFA $^{2}$ & $6.97 \times 10^{-10}$ & 4.816 & 0.000 \\
\hline $\mathrm{ST}$ & $-0.545^{\star 4}$ & -3.332 & 0.001 \\
\hline NOE & -0.392 & -5.663 & 0.000 \\
\hline $\mathrm{NOE}^{2}$ & $0.020^{\star 4}$ & 4.152 & 0.000 \\
\hline $\mathrm{CP}$ & -0.509 & -3.301 & 0.001 \\
\hline AGE & -0.008 & -1.390 & 0.167 \\
\hline MSD & $-0.077^{+4}$ & -2.262 & 0.026 \\
\hline $\mathrm{MSD}^{2}$ & 0.004 & 1.985 & 0.050 \\
\hline RES & -0.102 & -0.286 & 0.776 \\
\hline COMP & -0.207 & -1.585 & 0.116 \\
\hline RES*INCOME & $-1.56 \times 10^{-6}$ & -0.076 & 0.940 \\
\hline OWN & -0.097 & -0.638 & 0.525 \\
\hline NOMO & $-0.006^{\star 4}$ & -4.454 & 0.000 \\
\hline THEME & 0.378 & 3.255 & 0.002 \\
\hline EFFD & -11.831 & -4.095 & 0.000 \\
\hline $\mathrm{EFFD}^{2}$ & $22.880^{* 4}$ & 2.714 & 0.008 \\
\hline RVM & $0.627^{+44}$ & 4.836 & 0.000 \\
\hline R-squared & 0.871 & & \\
\hline Adjusted R-squared & 0.850 & & \\
\hline F-statistic & 40.930 & & \\
\hline
\end{tabular}

** Significant at the $1 \%$ level

- Significant at the 5\% level

- Significant at the $10 \%$ level

\section{Physical characteristics effects}

We have confirmed that internal floor area has a negative effect on the PFV of the shopping centre and the result is statistically significant at the $1 \%$ level. In other words, more window shoppers are found in the larger shopping centres.

We have also proved that number of storeys has a negative impact on the PFV of the 
shopping centres. We model the effect of high-rise shopping centre on PFV using a dummy variable which equals to 1 if the total number of storeys is larger than a critical number $\mathrm{n}$. The value of $\mathrm{n}$ is determined by trial and error starting with 2 and increasing by one in each trial. The smallest value of $\mathrm{n}$ that makes the dummy variable significant is critical floor level that distinguished "high-rise" from "low-rise" shopping centre in the calculation of PFV. Our data shows that the critical value is 13 and the coefficient of the dummy variable is negative and significant at the $1 \%$ level. PFV of multi-storey shopping centres with total number of storeys larger than 13 (high-rise) is lower than those with less than 13 storeys (low-rise). Even though a multi-storey shopping centre is usually with a high total floor area, the average per floor area is usually lower. The pedestrian flow in the multi-storey shopping centre always focuses on the most convenient floors which are usually the first few entrance levels. Due to this "entrance blockage", some potential higher level shoppers may be hindered from getting to the upper floors for shopping.

Regarding the number of entrances, it is with a negative impact at the $1 \%$ level on the PFV of the shopping centre. In other words, more number of entrances only means that the shopping centre is with a layout design to enable people to enter and exit easily. A high number of passing by people cannot contribute to the total sales of the shopping centre.

The effect of car park is negative at the $1 \%$ level. This finding confirms that many private car shoppers come in group with companions that are not buying things in the shopping centre.

Last, we have proved that building age effect is insignificant as retail properties can use renovation and decorations to rejuvenate the shopping centres' physical age and prevent them from becoming obsolesced.

\section{Location characteristics effects}

About the location effects, we have confirmed that distance from the major shopping district (MSD) has a negative effect on the PFV of the shopping centres. The result is statistically significant at the 5\% level. However, the effect of the types of the adjacent property is insignificant. Although the market positioning of these shopping centres may vary, both the residential and non-residential shopping centres got its loyal customers. As well, the effect of neighbourhood competitor shopping centre is also insignificant. Even if a shopping centre is with competitor shopping centres nearby, it does not mean that the average per person purchase in this shopping centre can be significantly affected by its competitors. In addition, the result also shows that the nearby catchment area's median household income effect is insignificant. This is indeed a finding to support the diminished location effect in a high density city with a well-developed public transportation system where cross district shopping is usually very common. 


\section{Owner and tenant effects}

In this study, we have found that the majority ownership effect on the PFV is insignificant. Even though a single (or majority) ownership shopping centre is usually doing better in property management of common areas, physical upgrading, and marketing promotions, the multi-owned shopping centres' advantages on tenancy variations and flexibilities is still something that the major owned shopping centres cannot outshine.

Nevertheless, it is very interesting to find that the effect on owner of multiple shopping centres is with a negative effect on the PFV of the shopping centres. The result is statistically significant at the $1 \%$ level. Owners with larger number of shopping centres in hand usually have a corporate strategy for managing its shopping centres. To facilitate the development of their shopping centres' branding and to achieve scale effect, a consistent pedestrian flow management strategy is usually applied to all the shopping centres owned by the company. However, this kind of uniform management strategy may not be suitable for all shopping centres under the same umbrella. For example, the management may like to implement a promotional campaign in a comprehensive shopping centre in the CBD aimed at increasing the pedestrian flows. Likewise, similar campaign is also applied to other shopping centres aimed at achieving promotional image of the company because the marginal cost is small. The pedestrian flows of other kinds of shopping centres patronized by a very different kind of shoppers (for example, the theme shopping centre in a remote area) are likewise increased. Paradoxically, we have found that the retailers of these shopping centres may not be benefited from the increase in pedestrian flows. Therefore, an assortment of different kinds of shopping centres owned by the same owner appears to have a lower PFV in this research.

About the tenant characteristics, we have proved that themed shopping centre is with a positive effect of $1 \%$ significant on the PFV of the shopping centre. As mentioned above, themed shopping centre is a place concentrated with most of the shops selling the similar kind of merchandises where most of the pedestrians are purposed shoppers.

\section{Entrance floor flow density effect}

About the EFFD effect, it has a negative impact on the PFV of the shopping centres and the result is statistically significant at the $1 \%$ level. In fact, a shopping centre with high pedestrian flow may imply that there is also a certain amount of window shoppers who cannot directly contribute on the PFV of the shopping centre. On the contrary, an overcrowded shopping centre may cause negative effect on the PFV as pedestrian jammed can create negative purchasing ambience to the shoppers of the shopping centre.

\section{Rateable value effect}

We have confirmed that rateable value is with a positive impact of $1 \%$ significant on the PFV of the shopping centre. Understandably, tenants of the high rental shops may often need to provide more luxury merchandises in order to cover their high rental expenses. On the other hand, the shoppers that go for high value items would also like to go to the 
high-end shopping centres for their target products.

\section{Concluding Remarks}

This study identifies the key determinants of the value of pedestrian flow (PFV) which is a measure of the value of pedestrian flow to the owners of shopping centres in the research. PFV is measured by net rental income per floor area per pedestrian flow. As the increase of pedestrian flow involve costs that may affect the profit of the shopping centre, it is important for the shopping centre owners to understand the factors affecting PFV of their shopping centres when implementing strategies to increase pedestrian flow in their shopping centres. Based on the rental and pedestrian flow survey data of 128 shopping centres along the MTR stations (include Light Rail and the former KCR) in Hong Kong, we have examined the marginal effects of these determinants of PFV of the shopping centres. These determinants explain approximately $90 \%$ of variations in these studied areas. We have found that the effects of most determinants are as expected. The effects of these determinants are summarized in the table below:

Summary of Findings of the Study on PFV

\begin{tabular}{|c|c|c|}
\hline Factors & Expected Results & Results in the Research \\
\hline Internal Floor Area & -ve & -ve $(1 \%)^{*}$ \\
\hline No. of storeys & -ve & -ve $(1 \%)^{*}$ \\
\hline No. of entrances & -ve & -ve $(1 \%)^{*}$ \\
\hline Car park & -ve & -ve $(1 \%)^{*}$ \\
\hline Building age & $?$ & Insignificant \\
\hline Distance from MSD & -ve & $-\operatorname{ve}(5 \%) *$ \\
\hline Residential shopping centre & -ve & Insignificant \\
\hline $\begin{array}{l}\text { Close to competitor shopping } \\
\text { centres }\end{array}$ & -ve & Insignificant \\
\hline Median Household Income & $+\mathrm{ve}$ & Insignificant \\
\hline Major ownership & $+\mathrm{ve}$ & Insignificant \\
\hline $\begin{array}{l}\text { Owner of multiple shopping } \\
\text { centres }\end{array}$ & -ve & -ve $(1 \%)^{*}$ \\
\hline Themed shopping centre & + ve & $+\mathrm{ve}(1 \%)^{*}$ \\
\hline Entrance floor flow density & -ve & -ve $(1 \%)^{*}$ \\
\hline Rateable Value & $+\mathrm{ve}$ & + ve $(1 \%)^{*}$ \\
\hline
\end{tabular}

* Figure inside brackets are significance level

\section{Areas of Future Research}

Since pedestrian flow cannot be increased without cost, a natural extension of this study is to find out the cost of increasing pedestrian flow or the pedestrian cost function, which is also a pedestrian flow management strategy. Together with the pedestrian value function in this study, we can identify an optimal pedestrian flow strategy for shopping centres. As well, all the sample shopping centres selected for this study are located along the railway stations. For the similar studies in the future, it is recommended to also study the centres that are with longer distance or less effect from the railway transportation. 


\section{References:}

Anonymous. (1969). Super Markets of the 70's, Part II: The Customer. Progressive Grocer. 58 (July): 55-60.

Cheung, C.Y. \& Lam, W.H.K. (1998). Pedestrian Route Choices Between Escalator and Stairway in MTR Stations. Journal of Transportation Engineering. C., 123(3), 277-285.

Chun, G.H., Eppli, M.J. \& Shilling, J.D. (2001). A Simulation Analysis of the Relationship between Retail Sales and Shopping Center Rents. Journal of Real Estate Research. Vol. 21, No. 3-2001.

Daamen, W. \& Hoogendoorn, S.P. (2003). Experimental Research of Pedestrian Walking Behavior. TRB 2003 Annual Meeting CD-ROM.

Davies, R.L. (1977). Store Location and Store Assessment Research: The Integration of Some New and Traditional Techniques. Transactions of the Institute of British Geographers. New Series: 2, 141-157.

Eppli, M. J. \& Shilling, J.D. (1996). How Critical is a good location to a regional shopping Center. The Journal of Real Estate Research, 12(3).

Fung, C.K. (2000). Determinants of Rents in the Theme Malls in Hong Kong. MSc Thesis. The University of Hong Kong.

Gambill, M.G. (2000). Shopping Center Branding: Does it make sense? Real Estate Issues: Spring 2000, Vol. 25, No.1, ABI/INFORM Global, 13-27

Kenney, M.T. (2000). Quantifying Business Enterprise Value in Shopping Malls: Current Issues \& Future Trends. The Appraisal Journal. July.

Lea, A.C. \& Menger, G.L. 1991. An Overview of Formal Methods for Retail Site Evaluation and Sales Forecasting: Part 3, Location-Allocation Models. The Operational Geographer. 9(1), 17-26.

Moss, M. (2007). Shopping as an entertainment experience. Lexington Books.

Ordway, N., Alexander, B., \& Eakin, M.E. (1988). Developing a Visibility Index to Classify Shopping Centers. The Appraisal Journal. Apr. 1988, 56(2), 233-242.

Planning Department, HKSAR (2007). Pedestrian Plan for Causeway Bay Technical Note.

Ownbey, K.L., Davis, K. \& Sundel, H.H. (1994). The Effect of Location Variables on the Gross Variables on the Gross Rents of Neighborhood Shopping Centers, 9(1).

Reimers, V. \& Clulow, V. (2000). Shopping and Convenience: A model for Retail Centres. A Model for Retail Centres. ANZMAC 2000 Visionary Marketing for the $21^{\text {st }}$ Century: Facing the Challenge.

Sicard, A. (2001). One-stop Shopping. Shopping Center World. Atlanta: Sept., 30, (9), 54. 
Simkin, L.P. (1989). SLAM: Store Location Assessment Model - Theory and Practice. OMEGA International Journal of Management Science. 17(1), 53-58.

Singer, D.D. \& Rosecky R. (1995). Reshaping the Community Shopping Center. Journal of Property Management. Dec.

Sirpal, R. (1994). Empirical Modeling of the Relative Impacts of Various Sizes of Shopping Centers on the Values of Surrounding Residential Properties. The Journal of Real Estate Research March, 9(4).

Skyat-Kengingwiluya, K. (2002). The Search for Self Images in Consumption Society of Shopping Malls in the Baltimore Metropolitan Area. PhD Thesis. Department of Anthropology \& Faculty of the Graduate, School of the University of Kansas.

Sloot, L.M., Verhoef, P.C., \& Franses, P.H. (2005). The impact of brand equity and the hedonic level of products on consumer stock-out reactions. Journal of Retailing. 81, 15-31.

The Economist. Reviving American downtowns. Thursday 01 March 2007.

Tse, C.W. (2002). The Relation between the customer behaviour and shopping centre promotion: A case study of Whampoa Garden. Dissertation, MSc in Housing Management. The University of Hong Kong. December 2002. 